Scientific Journal Warsaw University of Life Sciences - SGGW

Problems of World Agriculture volume 17 (XXXII), number 4, 2017: 172-181

DOI: $10.22630 /$ PRS.2017.17.4.93

Dorota Koziol-Kaczorek ${ }^{1}$

Warsaw University of Life Sciences - SGGW

\title{
The Plant Production in Norway
}

\begin{abstract}
A problem of the Norwegian agricultural policy, a description of the current types of subsidies for plant production and ongoing changes in the plant production in the years 2001-2016 is presented in this paper. There are also short information about topography of Norway and climate conditions. The main aim of the publication is to characterize changes in the plant production in the considered period. There is not too many publications about the Norwegian agriculture and plant production. The data from Statistiska Sentralbyrå (Statistics Norway) were used in the quantitative analysis. The results indicate the slight changes in the plant production in Norwegian agriculture i.e. decrease of number of holdings with plant, decrease of area of crops and size of yields.
\end{abstract}

Key words: plant production, climate conditions, topography, subsidies, agriculture in Norway

JEL Classification: Q12, Q15, Q20, Q21, Q24, Q29,

\section{Introduction}

Present publication is about a plant production in Norway. This study is a continuation of researches which have been conducted in a framework of "Scholarship and Training Fund Mobility Projects In Higher Education. Individual Training Programme For Staff Training Mobility" in Østfold University College in Norway. It is a continuation of published discussions devoted to the Norwegian agriculture, agricultural policy and Norwegian livestock production.

Agriculture in Norway is a challenging task. Norwegian topographic and climatic conditions gives some obvious challenges when it comes to self-sufficiency, security and especially profitability in the field of agricultural production (Vaale-Hallberg, 2012). Norway is both one of the northernmost countries in the world and at the same time one of the most mountainous. A significant part of the country is occupied by the Scandinavian Mountains. The average altitude is $460 \mathrm{~m}$, and 32 per cent of the area is above the tree border.

The climate of Norway is very diverse. On the south-western and partly southern coast the climate is moderate sea. In the lowlands in the south-east is moderate cold. The subpolar climate occurs on the north-west coast, while the continental climate is in the valleys and highlands below the tree line and on the north coast. Mountain tundra occurs above the tree line in all mountain areas. Arctic tundra occurs on Jan Mayen and the Svalbard archipelago, including Longyearbyen, as well as on the coastal belt from Cape North to Vardø. Arctic climate occurs only on Svalbard and Jan Mayen above $400 \mathrm{~m}$ above sea level (Uleberg, 2014).

Norway is geographically large in relation to its population and has diverse habitats. It is one of the least densely populated countries in Europe, with 17 inhabitants per $\mathrm{km}^{2}$.

${ }^{1} \mathrm{PhD}$, Department of Agricultural Economics and International Economic Relations, Faculty of Economic Sciences WULS - SGGW, ul. Nowoursynowska 166,02-787 Warszawa, e-mail: dorota_koziol@sggw.pl; https://orcid.org/0000-0001-7582-0810 
Built-up land (including roads) amounts to only about 2 per cent. A total of 3 per cent is agricultural land and 23 per cent is productive forest. A further 13 per cent is unproductive forest, while fresh-water resources and glaciers make up 7 per cent. The approximately 50 per cent that remains consists of mountains, plateau, bogs and moors (Statistics Norway, ssb.no). Many of habitats are not rugged with harsh climates. It causing significant challenges for agricultural and economic activity, even with modern technology and conveniences (Kozioł-Kaczorek, 2016b; OECD, 2016).

Norwegian holdings are typically small-scale farms requiring high input of labour, or are only suitable as grazing land for cattle or sheep. to Because of the climatic conditions, the season is short and there is high risk of damage to harvest. Moreover, Norway has one of the world's highest costs of living, and next-to-full employment. Thus, it is difficult to produce an average level of income based on competition with products from countries more suitable for industrial farming. As part of the compensation Norwegian agriculture is among the most subsidized and protected areas of food production in the world (Kozioł-Kaczorek, 2016b; OECD, 2016). The authorities generally counteract all attempts at reducing the high import tariff (Gaasland, 2009). Norway's comfortable fiscal position, thanks to oil wealth, gives it great possibilities on how to go about supporting agriculture and the rural sector (Hemmings, 2016).

The unfavourable topographic and climatic conditions, mentioned at the beginning, particularly affect the plant production, its type and structure. The aim of this paper is to present short characteristic of plant production in Norway, and changes in it during last years.

\section{Review of the literature}

The total agricultural and forest area is $80124 \mathrm{~km}^{2}$, that is a 26 per cent of land of the mainland part of Norway. The agricultural area in use covers $9859 \mathrm{~km}^{2}(3,2$ per cent of land) of which fully cultivated is $8103 \mathrm{~km}^{2}$ (2,7 per cent of land). It is sufficient to ensure the supply of the population of Norway in the meat, dairy product, vegetables and grain products to a certain extent (www.ssb.no, 2016; Kozioł-Kaczorek, 2016b). The share of agriculture in GDP was only 1.6 per cent in 2015. The agriculture share in employment was 1.8 per cent. The agro-food export was only 0.8 per cent of total export while the agro-food import was around 9.1 per cent of total import (Hemmings, 2016).

Table 1. The empirical distribution of areas of farms in 2016.

\begin{tabular}{c|cc}
\hline Area (ha) & Number of holdings & Structure ratio \\
\hline less than 4,9 & 5366 & $13,1 \%$ \\
$5,0-9,9$ & 7147 & $17,4 \%$ \\
$10,0-19,9$ & 10990 & $26,8 \%$ \\
$20,0-29,9$ & 6966 & $17,0 \%$ \\
$30,0-49,9$ & 6294 & $15,3 \%$ \\
50 and more & 4301 & $10,5 \%$ \\
\hline
\end{tabular}

Source: Own accounts based on Statistics Norway (www.sssb.no, 2017). 
The agricultural area covers $9859 \mathrm{~km}^{2}$ which is around 3,2 per cent of land. The fully cultivated area is $8103 \mathrm{~km}^{2}$ (2,7 per cent of land). The structure of agriculture in Norway is measured by numbers of holdings. In 2016 the total number of holdings was 41064 (www.ssb.no, 2016; Kozioł-Kaczorek, 2016a; Kozioł-Kaczorek, 2016b). Most of them were farms with an area between 10 ha and 20 ha, and it was around 27 per cent of total number of holdings. The empirical distribution of areas of farms in 2016 is presented in a Table 1 .

Most of the holdings are located in low-lying areas close to the main urban centres. The spatial distribution of holdings in generally in 2016 is presented on a map on the Figure 1.

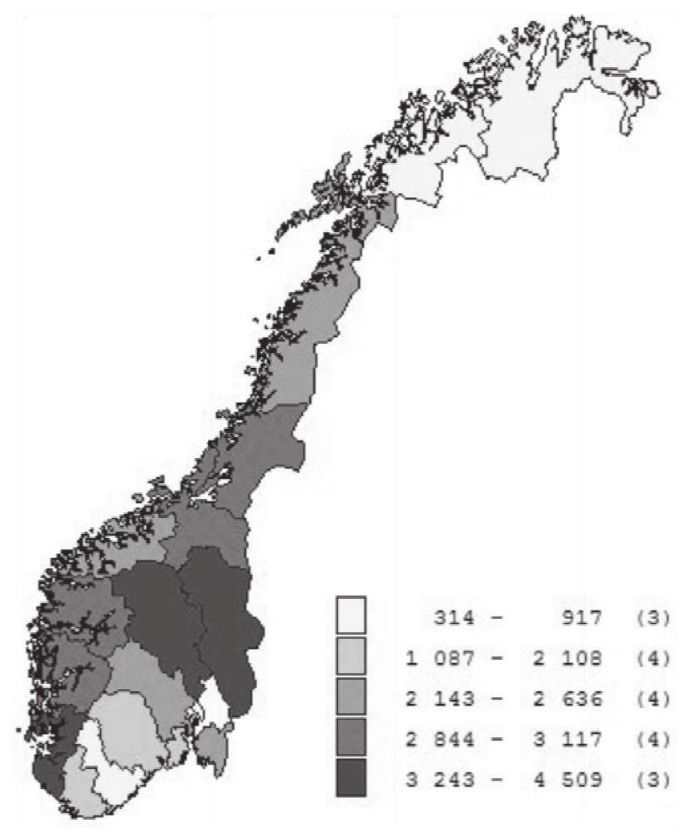

Fig. 1. The map of the spatial distribution holdings in generally (left map) and of the spatial distribution of holdings specialised in livestock farming (right map)

Source: Statistics Norway (www.sssb.no, 2017).

Spatial distribution of farms is determined by both topographical and climatic conditions. The short growing season is one of the limiting factors for agriculture in Northern Norway today. It limits the variety of possible crops and the yield potential. Consequently grassland occupies more than 90 per cent of the cultivated land in this area (Volden et al., 2002). The growing season is limited by the short and insufficient photoperiod which limits growth even if the temperature is sufficiently high. The most crops grown today are adapted to the long day light conditions at high latitudes, thus it can't be cultivated in this region. The weather conditions during winter also affects the soil situation in spring and thereby the possibilities for an earlier growing season start (Uleberg, 2016). Frequent "frost on snow-free soil" lead to thick layers of frozen soil, which keep soil temperatures low throughout spring even if other conditions favour an early start of the season. The winter conditions are the limiting factor for enhanced production potential in 
Northern Norway and the possible expansion of available crops might be limited by their ability to survive winter. Increased precipitation combined with more variable temperatures in winter cause snow to melt and refreeze, increasing problems with ice cover and encasement (Uleberg, 2016; Höglind et al., 2010; Bélanger et al., 2002). Similarly, periods of thaw and rain falling on frozen ground induce extensive and prolonged icing resulting in winter damage of pastures (Uleberg, 2016). Such overwintering problems are common in Northern Norway today, especially in the coastal regions of Troms and Nordland. These are important factors to consider when introducing new species and varieties. Because of climatic conditions, there is high risk of damage harvest (Uleberg, 2016).

As was mentioned before, the agriculture in Norway is a challenging task, especially the challenging task is the plant production. It's caused by both, mountainous areas and climate conditions. Nevertheless, there is a political consensus on having agriculture throughout the country. Wherefore, the agricultural production in Norway is strongly dependent on agricultural policy, which is based on (among other) the White Paper No. 9 (2011 - 2012) "On Norwegian agriculture and food production" approved in April 2012 (Kozioł-Kaczorek, 2016b). Furthermore, the objective of Norwegian agricultural policy is also to ensure self-sufficiency and security in the field of agricultural production (especially food production). It is a main reason for which the Norwegian agricultural policy is still strongly state regulated through legislation and economic instruments (Kozioł-Kaczorek, 2016b; Forbord et al., 2014; Dramstad et al., 2010). The key policy instruments supporting agriculture include domestic market regulation, budgetary payments, support measures, certain product price, welfare schemes and also border measures (Kozioł-Kaczorek, 2016b; Hemmings, 2016). The most important support for holdings comes via direct and indirect assistance for farmers. There is a lot of individual mechanism. The key types of support comprises output-based support, transport subsidies, acreage-based payments and headage payments (Koziol-Kaczorek, 2016b; Hemmings, 2016). The mentioned above core support mechanisms are augmented by a lot of other programmes that, for example, compensate farmers in the event of natural disasters or losses due to predators. Furthermore, farmers can also benefit from a special tax relief (Hemmings, 2016). There are different kind of types of support for holdings with the plant production. The first one is output-based payments for fruit and vegetables, cereals (Hemmings, 2016). Another one type are transport subsidies i.e. various schemes supporting transport of grains. The next type are acreage-based payments. Further types of support are financial assistance with labour input and other national payment schemes include: organic farming support, natural disaster compensation, compensation programmes for losses due to predators and other losses (Hemmings, 2016). There are also regional environmental programme and income-tax deduction. Positive income balances are not taxed up to a maximum tax saving of NOK 44 900 (i.e. around EUR 4900 at an exchange rate of 9.2) per farmer (Kozioł-Kaczorek, 2016b; Hemmings, 2016).

Except budgetary support, every year, the Government and organizations of farmers negotiate the annual agriculture agreement, which sets out i.e. the target prices that ought to be obtained for agricultural products, taking into account the market conditions, import restrictions and applicable market regulation. In order to achieve the annual set target prices, effective customs barriers are placed to avoid outstripping from foreign products being low-priced compared to Norwegian products (Vaale-Hallberg, 2012; Gaasland, 2009). 


\section{Methods and data}

As mentioned earlier, the purpose of the publication is a short description of plant production in Norway, and changes occurring in it during last years.

The data used in the analysis were collected through a website of Statistiska Sentralbyrå (Statistics Norway). The collected data include information about the structure of agriculture i.e. the number of agricultural holdings, their size and type of farming and the input of agricultural area in use and number of livestock. Furthermore, the set of data include information about cereals and oil seeds (area and yields), horticultural production (area and yields), production of potatoes and forage plants (area and yields). The used definitions of the main concepts and variables were taken from Statistics Norway. Thus, an agricultural holding is understood as a single unit both technically and economically, which has single management and which produces agricultural products. The holding is independent of municipality boundaries. The agricultural holding's headquarter must be located to an agricultural property. An agricultural area in use is an agricultural land that is harvested at least once during a year, including planted area of permanent crops, where no harvest has been produced so far. Includes also arable land included in the crop rotation system with no intention to produce a harvest during the year, but which will be harvested the next year. The type of farming of a holding is determined by the contribution ratio of the different crop and livestock enterprises to its total agricultural production (ssb.no).

Statistical data analysis methods have been used in quantitative research.

\section{Results}

In 2016, there were 11173 holdings with area of grain and oil seeds in Norway, and it was around 0,84 per cent less than in 2015. The changes in number of holdings with area of grain and oil seed in the period from 2001 to 2016 are presented on the Figure 2.

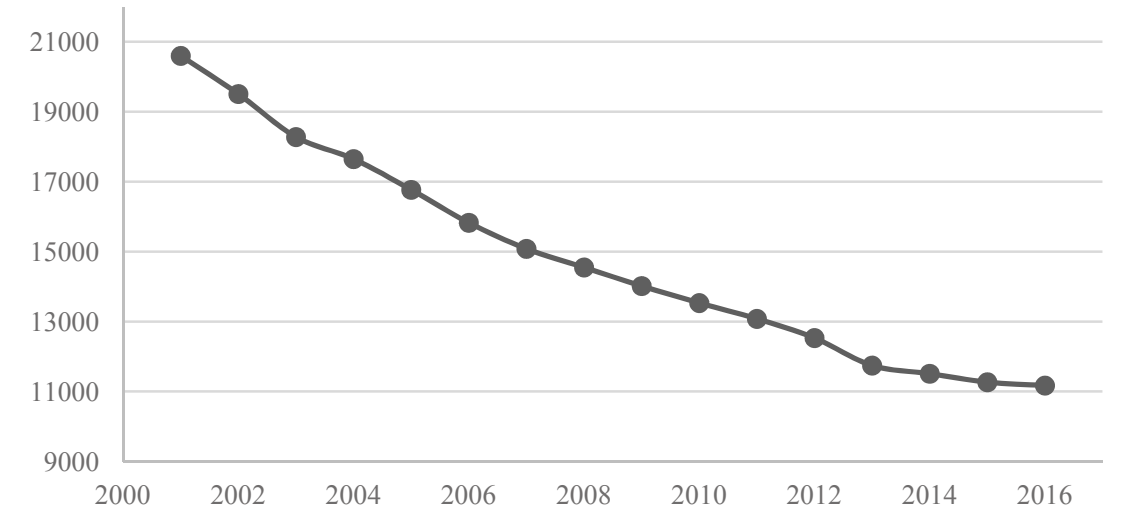

Fig. 2. The changes in number of holdings with area of grain and oil seed.

Source: Statistics Norway (www.sssb.no, 2017). 
During fifteen years the number of holdings with area of grain and oil seed was decreasing annually on average about 4 per cent. The spatial distribution of the number of holdings with area of grain and oil seeds is presented on the Figure 3.

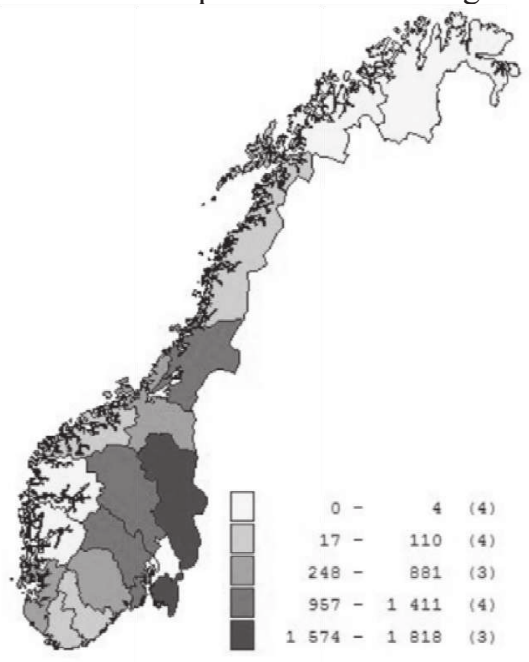

Fig. 3. The map of the spatial distribution of holdings with area of grain and oil seeds.

Source: Statistics Norway (www.sssb.no, 2017).

As can be seen, the biggest number of holdings is located in Hedmark county in eastern of Norway and Østfold county in southern of Norway. Same spatial distribution is of course for the total area of grain cultivation. The total area of grain cultivation was 284 490 ha in 2016, and it was about 0,83 per cent more than in 2015. The area of grain cultivated has decreased by average of 0,95 per cent over the last fifteen years. Because of the short growing season in Norway, mainly barley is grown - around 48 per cent of total area of grain cultivated. Due to the share in the area of cereal crops on the second and third place are oats ( 26 per cent of total area of grain cultivated) and wheat (23 per cent of total area of grain cultivated). The total area of barley cultivation was 137180 ha in 2016, and it was about 11,27 per cent more than in 2015 . The area of barley cultivated has decreased by an average of 1,68 per cent over the last fifteen years. The total area of oats cultivation was 75970 ha in 2016, and it was about 20 per cent more than in 2015. The area of oats cultivated has decreased by an average of 0,74 per cent over the analysed period. The area of wheat cultivation was 66790 ha in 2016, and it was about 22 per cent less than in 2015. The area of wheat cultivation was increasing annually on average about 0,33 per cent over the last fifteen years. The described above changes in: the total area of grain, the area of barley, the area of oats and area of wheat in the period from 2001 to 2016 are presented on the picture 4.

The size of cereal yields over the last fifteen years has remained at the same level. In the 2016 the yields of barley was about 574000 tones, the yields of oats was about 330000 tones and the yields of wheat was about 286000 tones. 


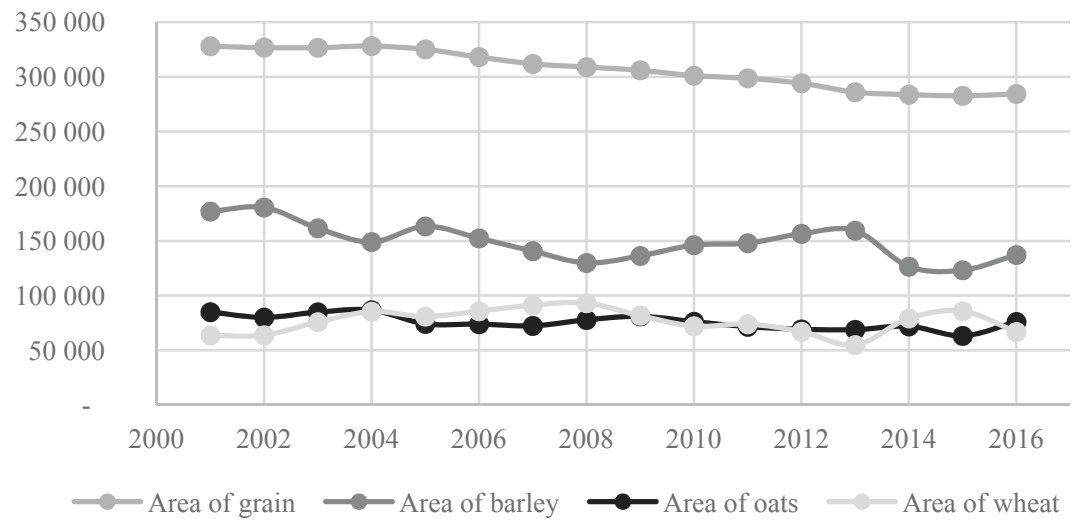

Fig. 4. The changes of area of holdings with area of grain and oil seed.

Source: Statistics Norway (www.sssb.no 2017).

In 2016, there were 1875 holdings in Norway with crop of potatoes, and it was about 4 per cent less than in 2015. The changes in number of holdings with crop of potatoes in the period from 2001 to 2016 are presented on the Figure 5.

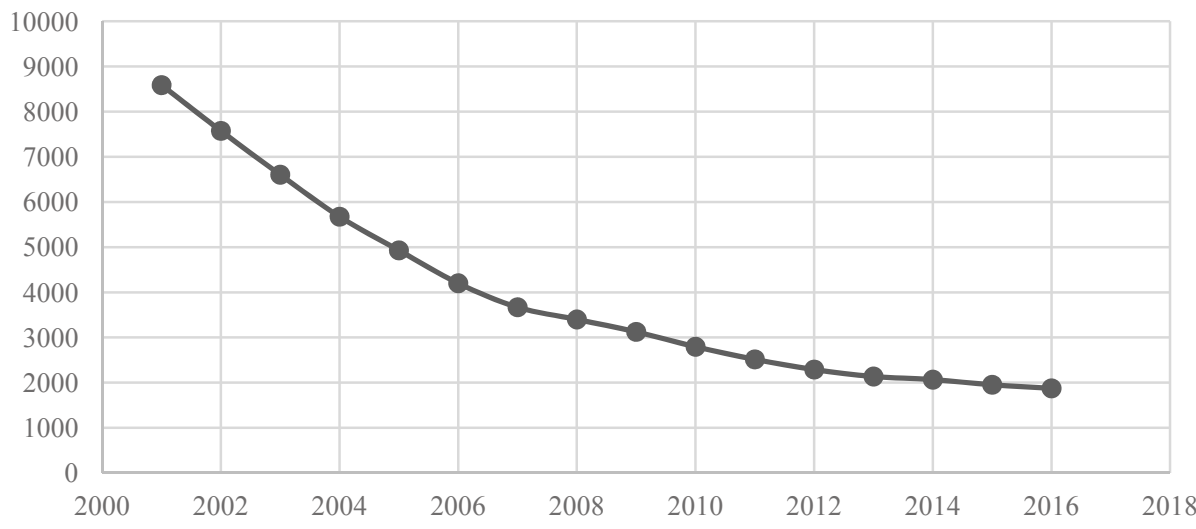

Fig. 5. The changes in number of holdings with crop of potatoes.

Source: Statistics Norway (www.sssb.no, 2017).

During last fifteen years the number of holdings with crop of potatoes was decreasing annually on average about 9,65 per cent. The spatial distribution of the number of holdings with area of grain and oil seeds is presented on the Figure 6.

As can be seen, the biggest number of holdings with the crop of potatoes is located in Hedmark county in eastern of Norway, Oppland county in central of Norway and in Nordland county in northern. The size of potatoes yields over the last fifteen years has remained at the same level. In the 2016 the yields of potatoes was about 363200 tones. 


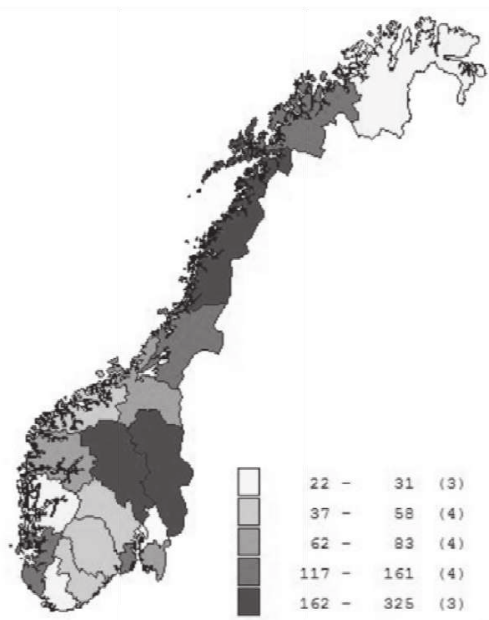

Fig. 6. The map of the spatial distribution of holdings with crop of potatoes.

Source: Statistics Norway (www.sssb.no, 2017).

The last branch of plant production (food production) is horticulture (also with the greenhouse production). Due to climatic conditions and soil quality, gardening is limited to some fruits and vegetables. The largest area has carrot crops (1 608 ha, 8 per cent more than in 2015), strawberry plantations (1 532 ha, 6 per cent less than in 2015) and apple orchards (1 351 ha, 2 per cent less than in 2015). A slightly smaller area is occupied by onion cultivation ( 827 ha, 2 per cent less than in 2015) and cauliflower (644 ha, 17 per cent more than in 2015). The average annual changes of area of mentioned above crops are presented in the Table 2 .

Table 2. The average annual changes of area.

\begin{tabular}{l|c}
\hline \multicolumn{1}{c|}{ Crop } & Average annual change of area \\
\hline carrot & $2,46 \%$ \\
strawberry & $1,62 \%$ \\
apples & $-0,93 \%$ \\
onion & $4,81 \%$ \\
cauliflower & $7,37 \%$ \\
\hline
\end{tabular}

Source: Own accounts based on Statistics Norway (www.sssb.no, 2017).

Only in case of apple orchards the area was decreasing gradually during last 6 years. The biggest increased of area is for crop of cauliflower. Areas of the other fruits and vegetables crops are presented in Table 3. 
Table 3. Areas of the other fruits and vegetables crops

\begin{tabular}{c|l}
\hline Area (ha) & \multicolumn{1}{c}{ Kind of crop } \\
\hline $10-100$ & $\begin{array}{l}\text { table swedes, plums, broccoli, raspberry, other lettuces field-grown, iceberg lettuce, winter cabbage, } \\
\text { black currant, brussels sprouts, leek, sweet cherries, beetroots, radishes, chinese cabbage, early } \\
\text { cabbage } \\
\text { root celery, sweet corn, pears, turnips, other berries, ridge cucumber, cherries, red cabbage, celery, } \\
\text { bilberry }\end{array}$ \\
\hline
\end{tabular}

Source: Own accounts based on Statistics Norway (www.sssb.no, 2017).

The average annual changes of area of mentioned above crops are presented in the Table 4. The results are ordered due to the size and direction of changes.

Table 4. The average annual changes of area of the other fruits and vegetables crops

\begin{tabular}{|c|c|c|}
\hline \multicolumn{2}{|c|}{ Average annual change of area (per cent) } & Crop \\
\hline \multirow{2}{*}{ decrease of } & $4-8$ & $\begin{array}{l}\text { chinese cabbage, other berries, pears, sweet cherries, ridge } \\
\text { cucumber }\end{array}$ \\
\hline & $0-4$ & $\begin{array}{l}\text { iceberg lettuce, bilberry, celery, broccoli, early cabbage, cherries, } \\
\text { red cabbage }\end{array}$ \\
\hline \multirow{5}{*}{ increase of } & $0-4$ & $\begin{array}{l}\text { early cabbage, cherries, red cabbage, table swedes, red cabbage, } \\
\text { table swedes, plums }\end{array}$ \\
\hline & $4-8$ & leek, winter cabbage, root celery, brussels sprouts \\
\hline & $8-10$ & beetroots \\
\hline & 11,36 & other lettuces field-grown \\
\hline & 24,71 & radishes \\
\hline
\end{tabular}

Source: Own accounts based on Statistics Norway (www.sssb.no, 2017).

The biggest decrease of the area of crop concerns chinese cabbage and other berries. On the other hand, the largest increase of the area of crop is for radishes. The changes of size of yield in horticulture are presented in the Table 5 .

Table 5. The changes of size of yield in horticulture

\begin{tabular}{|c|c|c|}
\hline \multicolumn{2}{|c|}{ Average annual change of area (per cent) } & Crop \\
\hline \multirow{5}{*}{ decrease of } & 26,69 & bilberry \\
\hline & 13,72 & cherries \\
\hline & 11,28 & pears \\
\hline & 9,7 & chinese cabbage \\
\hline & $0-6$ & $\begin{array}{l}\text { ridge cucumber, other berries, red cabbage, early cabbage, sweet } \\
\text { cherries, turnips, table swedes }\end{array}$ \\
\hline \multirow{4}{*}{ increase of } & $0-8$ & $\begin{array}{c}\text { strawberry, sweet corn, celery, broccoli, apples, brussels sprouts, } \\
\text { carrot, plums, iceberg lettuce, winter cabbage, cauliflower, } \\
\text { raspberry, onion, leek, root celery }\end{array}$ \\
\hline & $8-9$ & radishes, black currant \\
\hline & 14,78 & beetroots \\
\hline & 23,85 & other lettuces field-grown \\
\hline
\end{tabular}

Source: Own accounts based on Statistics Norway (www.sssb.no 2017). 
Let us notice that both, structure of changes of area of crop and the structure of changes of size of yield are not the same. And it is quite obvious, because size of yield depends on a lot of significant determinants, not only area of crop.

\section{Conclusions}

Mountainous terrain, unfavourable climate, short vegetation period and weak soils naturally limit the possibilities of crop production in Norway. Moreover, the high cost of living and next-to-full employment makes that the agriculture production is costly and unprofitable. Only a very few industrial farmers in Norway are able to produce an average level of income based on the own production. The vast majority of holdings has to be a beneficiary of numerous aid programs and subsidies. Almost in every area of plant production there is a noticeable decrease in both the area of crops and the size of crops.

Because of the climate conditions, the short vegetation period and topography the majority of crop production is concentrated in the southern part of Norway, especially in Hedmark county. In the northern part of Norway the plant production almost doesn't exist.

It is obvious that the subject of agricultural production has not been exhausted. Further research and publications are planned on this issue.

\section{References}

Bélanger, G., Rochette, P., Gastonguay, Y., Bootsma, A., Mongrain, D., Ryan, D. (2002). Climate change and winter

survival of perennial forage crops in Eastern Canada. Agronomy Journal, 94, 1120-1130.

Dramstad, W.E., Sang, N. (2010). Tenancy in Norwegian agriculture. Land Use Policy, 27, 946-956.

Forbord M., Bjørkhaug,H., Burton R.J.F. (2014). Drivers of change in Norwegian agricultural land control and the emergence of rental farming. Journal of Rural Studies, 33, 9-19.

Hemmings, P. (2016). Policy Challenges for Agriculture and Rural Areas in Norway. OECD Economics Department Working Papers, No. 1286, OECD Publishing, Paris. DOI: http://dx.doi.org/10.1787/5jm0xf0r676c-en

Höglind, M., Bakken, A.K., Jørgensen, M., Østrem, L. (2010). Tolerance to frost and ice encasement in cultivars of timothy and perennial ryegrass during winter. Grass and Forage Science, 65, 431-445.

Kozioł-Kaczorek, D. (2015). Agricultural property market in Norway - basic information. Scientific Journal WUoLS-SGGW Problems of World Agriculture, 15(4), 119-126.

Kozioł-Kaczorek, D. (2016a). Struktura obszarowa rolnictwa w Norwegii. Zeszyty Naukowe Szkoły Głównej Gospodarstwa Wiejskiego Problemy Rolnictwa Światowego, 16(3), 212-220.

Kozioł-Kaczorek, D. (2016b). The livestock production in Norway. Scientific Journal WUoLS-SGGW Problems of World Agriculture, 16(4), 188-195.

OECD (2016). "Norway" in Agricultural Policy Monitoring and Evaluation 2016, OECD Publishing, Paris. DOI: http://dx.doi.org/10.1787/agr pol-2016-21-en.

Ulberg, E., Hanssen-Bauer, I., Van Oort, B., Dalmannsdottir, S. (2014). Impact of climate change on agriculture in Northern Norway and potential strategies for adaptation. Climatic Change, 122, 27-39.

Ursin, L., Myskja, B.K., Carson, S.G. (2016). Think Global, Buy National: CSR, Cooperatives and Consumer Concerns in the Norwegian Food Value Chain. Journal of Agricultural and Environmental Ethics, $29,387-405$.

Vaale-Hallberg, M. (2012). Norway: A New Model for Customs Duties Giving a Higher Protection to Norwegian Agriculture (Report). European Food and Feed Law Review, 7(6), 350-351.

www.regjeringen.no.

www.statbas.ssb.no. 